\title{
A Direct Approach for Quantifying Stream Shading
}

\author{
Patrick E. Clark, ${ }^{1}$ Douglas E. Johnson, ${ }^{2}$ and Stuart P. Hardegree ${ }^{3}$
}

Authors are ${ }^{1}$ Range Scientist and ${ }^{3}$ Plant Physiologist, Northwest Watershed Research Center, USDA Agricultural Research Service, Boise, ID 83712-7716, USA; and ${ }^{2}$ Professor, Department of Rangeland Ecology and Management, Oregon State University, Corvallis, OR 97331-2218, USA.

\begin{abstract}
Management and regulatory standards for stream shading have been established to mitigate excessive stream temperature. Existing shade assessment tools, however, are inadequate for monitoring extensive stream networks. Our objectives were to develop and evaluate an efficient, low-cost field technique for sampling stream-surface shading using digital images and to evaluate the efficiencies and effectiveness of eight different digital image analysis techniques for shade assessments. We developed a quadrat-based technique and associated field equipment to directly photograph stream-surface shading. Sampling at random points (pixels) within the resultant digital images was the most accurate, efficient, and robust image analysis technique. An approach pairing the photographic field technique and the random point-sampling image analysis technique should enable managers to conduct ground-based assessments of stream shading over extensive stream networks. This approach may also provide an efficient means of collecting ground truth samples for even broader scale, remote sensing-based streamshade assessments.
\end{abstract}

\section{Resumen}

Estándares para el manejo y regulación de sombras sobre corrientes de agua han sido establecidos para mitigar las temperaturas excesivas en las mismas. Las herramientas existentes para la evaluación de sombras son, sin embargo inadecuadas para el monitoreo extensivo de las redes de drenaje. Nuestros objetivos fueron desarrollar y evaluar una técnica de campo eficiente y de bajo costo para muestrear la sombra sobre la superficie de las corrientes de agua usando imágenes digitales, y evaluar las eficacias y eficiencias de ocho diferentes técnicas de análisis de imágenes digitales para las evaluaciones de sombra. Hemos desarrollado una técnica basada en cuadrantes y asociada al equipo de campo para fotografiar directamente la sombra en la superficie de la corriente de agua. Un muestreo de puntos al azar (pixeles) dentro de las imágenes digitales resultantes fue la técnica de análisis de imagen más precisa, eficiente, y robusta. Una estrategia combinando la técnica fotográfica de campo y la técnica robusta de muestreo de puntos al azar con imagines digitales podría permitir a los usuarios llevar a cabo evaluaciones de campo extensivas de las sombras existentes sobre las corrientes de agua. Esta estrategia podría también proporcionar medios eficientes para recolectar muestras de campo incluso para evaluaciones de sombra a escalas más amplias usando metodologías basadas en sensores remotos.

Key Words: field technique, image analysis, measurement, monitoring, riparian, solar radiation, stream temperature, water quality

\section{INTRODUCTION}

Water temperature is a critical parameter affecting the ecology of rangeland stream systems. Elevated stream temperature can cause thermal stress in fish and aquatic invertebrates (Hawkins et al. 1997; Dickerson and Vinyard 1999; Cox and Rutherford 2000), reduced dissolved oxygen content in stream water (Cooter and Cooter 1990; Morrill et al. 2005), and increases in algae and other aquatic vegetation (Rutherford et al. 2000). As mandated by the Clean Water Act of 1972, regulatory standards have been developed for stream temperature. In this regulatory context, excessive thermal inputs to a stream are

This research was funded by the USDA Agricultural Research Service.

Mention of manufacturer, trademark name, or proprietary product does not constitute endorsement by the US Department of Agriculture or Oregon State University and does not imply their approval to the exclusion of other products that may also be suitable.

Correspondence: Patrick E. Clark, Northwest Watershed Research Center, USDA-ARS, 800 Park Blvd, Suite 105, Boise, ID 83712-7716, USA. Email: pat.clark@ars.usda.gov

Manuscript received 10 February 2007; manuscript accepted 19 December 2007. considered pollutants (US Environmental Protection Agency 2003). Many rangeland stream systems, particularly those in western states, are now considered thermally impaired and in need of mitigation.

Solar radiation is one of several inputs affecting stream temperature (Cox and Bolte 2007). Thermal input, consequently, is reduced where a stream surface is shaded by riparian vegetation, stream banks, and other streamside features (Rutherford et al. 1997; Malcolm et al. 2004). In forested systems, removal of the tree canopy has been demonstrated to impact stream temperature (Brown 1970; Moore et al. 2005). Although the efficacy of maintaining or increasing stream shading to mitigate excessive stream temperature is still being debated and evaluated (e.g., Larson and Larson 1996; Beschta 1997; Ice et al. 2004; Rutherford et al. 2004), management plans and environmental impact documents from numerous agencies have already begun to define stream shading standards for temperature mitigation.

A number of techniques developed for assessing tree canopy cover have been used by managers and researchers to indirectly 
assess stream shading (Davies-Colley and Payne 1998; DaviesColley and Rutherford 2005; Kelley and Krueger 2005; Teti and Pike 2005; Lhotka and Loewenstein 2006). These canopycover techniques, however, require models to estimate shade cast by trees and other streamside features rather than directly assessing shading on the stream surface (Chen et al. 1998). Although most of these techniques use large angles of view and, thus, may integrate canopy cover effects from a relatively large area overhead (Bunnell and Vales 1990; Nuttle 1997), each sample is still effectively a point sample, representing the canopy effects on only a single point in space. Point-sampling techniques require many more samples than two-dimensional or areal sampling techniques to adequately assess the variability occurring within a region of interest (Greig-Smith 1983; Bonham 1987). If costs per sample are similar, areal sampling can be considerably more efficient than point sampling.

Consequently, there is currently a lack of field and image analysis techniques for directly, accurately, and efficiently quantifying shading on the surface of rangeland streams. The objectives of this research were to develop and evaluate a field technique for rapidly collecting digital images as areal samples of stream-surface shading and then to evaluate cost, accuracy, and efficiency of different digital analysis techniques for analyzing stream-shade images.

\section{MATERIALS AND METHODS}

\section{Study Site}

The study areas for development of the stream shade-assessment field technique were two stream reaches, Dobson Creek (1003 m in length) and Reynolds Creek (1323 m long), located within the Reynolds Creek Experimental Watershed in southwestern Idaho (lat $43^{\circ} 11^{\prime} \mathrm{N}$, long $116^{\circ} 46^{\prime} \mathrm{W}$ ). Base elevations of Dobson and Reynolds reaches were 1486 and $1433 \mathrm{~m}$, respectively. Maximum, minimum, and mean annual air temperatures for a long-term climate monitoring station, located at a similar elevation and within $10 \mathrm{~km}$ of the study areas, were $12.1^{\circ}, 3.7^{\circ}$, and $7.9^{\circ} \mathrm{C}$, respectively (Hanson et al. 2001). Both study reaches were headwater streams where the stream width was typically $<2 \mathrm{~m}$ at low flow. Mean gradient of the Dobson reach was $8 \%$, and it was $2 \%$ for the Reynolds reach. Both reaches had sections where shading conditions ranged from unshaded (full solar exposure from 0800 to 1600 hours) to completely shaded. Steep stream banks and nearby hills provided some early morning and late evening shading in both reaches but did not contribute to midday shading levels. Riparian vegetation on both stream reaches included an overstory of mature black cottonwood (Populus balsamifera L. subsp. trichocarpa [Torr. \& Gray ex Hook.]) with a shrub layer of juvenile black cottonwood, willow (Salix spp.), red alder (Alnus rubra Bong.), and redosier dogwood (Cornus sericea L.), and an herbaceous understory of graminoids.

\section{Equipment}

Shade sampling was conducted using a $1-\mathrm{m}^{2}$ sampling board photographed from a height of $2 \mathrm{~m}$. The sampling board was constructed from an exterior-grade plywood board $(105 \times 122 \times 1.3 \mathrm{~cm}$; Fig. 1$)$. Loop-shaped handles were cut along the two short sides of the board. All the cut edges of the board were rounded with a router to prevent splintering. All surfaces of the board were painted with multiple coats of flat, black paint to provide water resistance and a nonreflective background for the photography. A sheet of flat-white countertop laminate $(100 \times 100 \mathrm{~cm})$, with edges slightly chamfered, was positioned on top of the board so that a 15 $\mathrm{cm}$ border was left uncovered at one end of the board. This $15-$ $\mathrm{cm}$ border allowed the investigator access to the handles and provided a sturdy location for mounting the camera mast, bull's-eye level, compass, and a dry-erase white board or field slate. On the opposite end of the board, where the loop handles were located, a $7-\mathrm{cm}$ border was left uncovered. A $2.5-\mathrm{cm}$ border was left along the two long sides of the board. Once properly aligned, the laminate sheet was permanently glued in place using waterproof contact cement formulated for countertop laminate. The white laminate served as a shade-sampling quadrat $\left(1 \mathrm{~m}^{2}\right)$. Strips of red plastic tape were applied to the board to help define each edge of the quadrat when viewing digital photography of the sample board.

The camera mast to support the camera, at $2 \mathrm{~m}$ above the sampling board, was constructed from a $183-\mathrm{cm}$ length of thick-walled, schedule-80 polyvinyl chloride (PVC) pipe $(3.8 \mathrm{~cm}$ in diameter; Fig. 1). A steel-bulkhead pipe fitting, which was painted flat black, was used to attach the camera mast to the sampling board. A short, steel-nipple fitting $(20 \mathrm{~cm}$ long) and a PVC union fitting were installed between the bulkhead fitting and the lower end of the mast. The union fitting allowed the mast to be easily removed from the board for transport. A PVC tee fitting $(3.8 \mathrm{~cm})$ with two glue-in reducers (3.8 to $2.5 \mathrm{~cm}$ in diameter) was installed on the upper end of the mast. This tee fitting was drilled and tapped to accept two nylon bolts $(0.64 \mathrm{~cm}$ in diameter) through the top.

The yardarm to which the camera was mounted was constructed using a $61-\mathrm{cm}$ length of copper pipe $(1.9 \mathrm{~cm}$ in diameter) with a threaded female fitting soldered to one end. A ball-head camera mount was threaded into the fitting on the yardarm (Fig. 1). For efficient field use, it was convenient to use a ball-head mount with a quick-release mechanism, which allowed easy and rapid removal of the camera. Once constructed, the yardarm was passed through the tee fitting on the mast and secured in place by tightening the two nylon bolts located on the tee fitting.

A digital camera was installed on the ball-head mount of the yardarm using the camera's tripod-mounting socket. Although any commonly available digital camera would be adequate, a camera with a hinged or rotating liquid crystal display (LCD) viewer was quite helpful because this feature allowed the operator to view the camera scene and confirm proper camera alignment and focusing while standing alongside the sampling board. Cameras with a fixed LCD viewer require the observer to ascend a ladder or nearby stream bank to periodically check the camera setup.

\section{Field Technique}

Shade sampling was conducted only on cloudless days when the contrast between sunlit and shaded regions of the sampling board was sharpest. Clouds or haze reduced that contrast. Overcast or extremely hazy days may entirely prevent detectable shadows from being cast. Lighting conditions, 


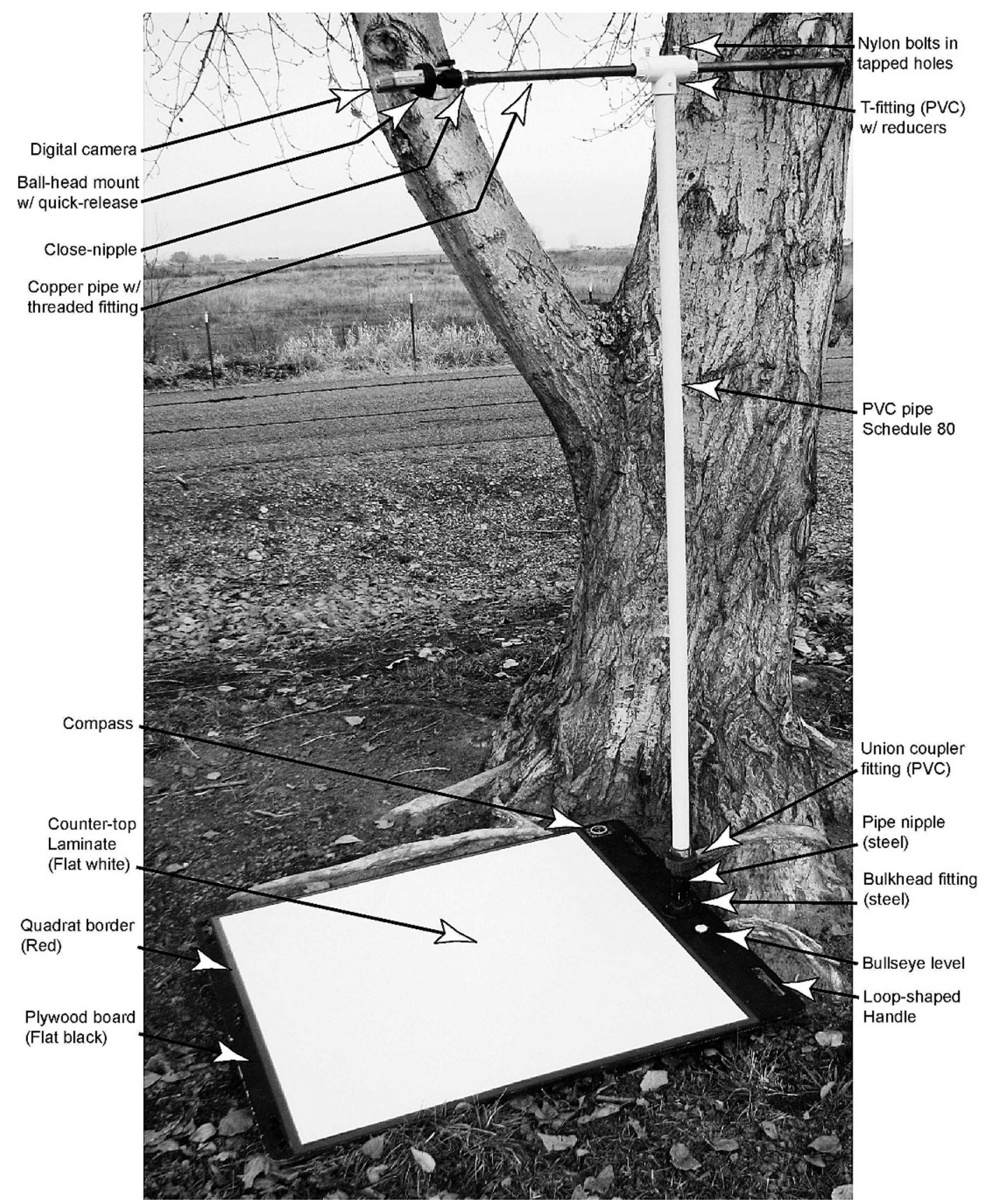

Figure 1. Stream-shade sampling board with 1- $\mathrm{m}^{2}$ quadrat (flat-white counter-top laminate), compass, bull's-eye level, loop handles, and steelbulkhead pipe fitting coupled with a polyvinyl chloride (PVC) union joint to serve as a removable mount for the camera mast.

including the presence of atmospheric haze, dust, or smoke, were noted on field data forms.

Stream reaches selected for sampling were representative of the riparian vegetation, channel morphology, and surrounding topography found in larger regions within the stream system. Shade-sampling points were established at equal intervals (20 $\mathrm{m}$, in this case) along the thalweg of each stream reach using a ruled tape. The interval distance between sample points was measured following the contour of the thalweg rather than as straight line. Although less practical, it may be more statistically appropriate to use random-interval distances rather than equal or fixed distances. In any case, to provide sample independence, the lower limit for sampling-interval distance should be dictated by the maximum length of shadow cast during the sampling period by vegetation or topographic features along the reach.

For ease of transport, the shading board was typically carried disassembled into the general sampling area and then assembled on site. Upon initial setup, the shading board itself was leveled and stabilized using a set of four wooden wedges and the bull's-eye level mounted on the board. Another bull's-eye level, placed on the camera back, was used to adjust the ballhead mount, so the camera focal plane was level and parallel to the sampling board. At this time, the ball-head mount was also used to orient the camera, so the view-frame edges were parallel with the edges of the sampling quadrat. 


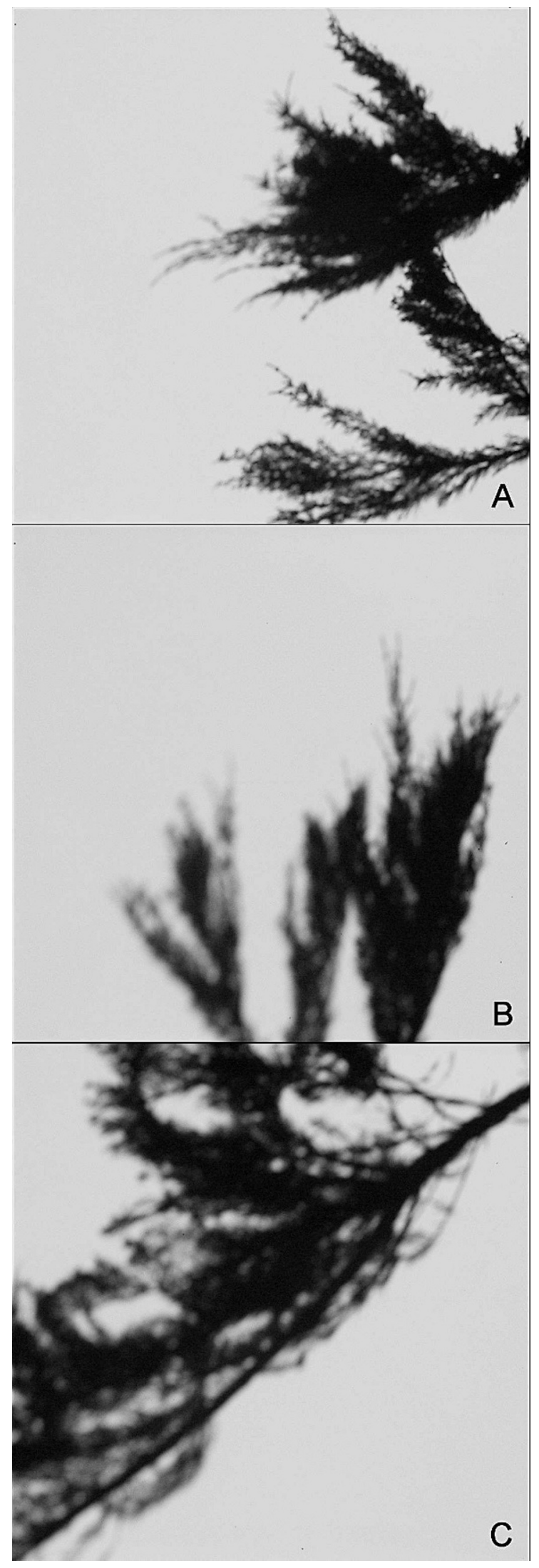

Figure 2. Cropped images of the shade-sampling quadrat $\left(1 \mathrm{~m}^{2}\right)$ shaded by willow (Salix spp.) branches, which were used in an evaluation of variability in percentage shade results that was due to the analyst. A, Test image 1 where $29.0 \%$ of the sampling quadrat was shaded as determined using the mean result from three sampling bouts,
Stream shade sampling was conducted by locating each sampling point, recording its location with a Global Positioning System (GPS) unit, and centering the board directly over the point. The compass on the board was then used to orient the board so the board edges were parallel to the cardinal directions. The camera mast was always located on the north side of the board to avoid having the camera mast cast a shadow on the board. We also installed steel rebar marker stakes $(0.64 \mathrm{~cm}$ in diameter) adjacent to two opposite corners of the shading board thus allowing precise repositioning of the board during later sessions. The board was supported by hand so its bottom surface was as near as possible to the stream surface. A remote shutter release was then used to acquire a digital photograph of the shade board. Typically, the elapsed time from arrival at the sample point until the sample was acquired was about $30 \mathrm{~s}$. The speed and ease of sample collection using this field technique facilitated repeated sampling of the same sampling points at different solar times of day (e.g., 0800, 1000, 1200, 1400, and 1600 hours) or at different times in the season, allowing one to investigate how stream shading changes over the course of the day and over the season.

\section{Image Preparation}

Images in which the sampling quadrat was obviously unshaded were recorded as such and excluded from additional processing. For remaining images, a digital image-processing software package (Paint Shop Pro 2000) was used to rotate each image slightly, if necessary, so that the lower (north) edge of the board was horizontal. Each original image was cropped, using a template in the software, to a final image of 1026 pixels by 1026 rows representing only the $1-\mathrm{m}^{2}$ quadrat.

\section{Image Analysis Technique Evaluation}

Eight different image analysis techniques were evaluated for accuracy and efficiency. Five analysts, with varying degrees of experience, applied each technique to three test images of differing levels of shading (Figs. 2A-2C). Each analyst applied the techniques in the order in which they are presented below. For each technique, analysts recorded the time required to complete the analysis and the percentage of shade in each test image.

Subjective Threshold. Each analyst used the Threshold tool in the Paint Shop Pro software to subjectively adjust a grayscale value threshold for each test image until a resultant black-andwhite image represented the shaded (black) and nonshaded (white) regions of the sampling quadrat with acceptable accuracy.

Objective Threshold. VegMeasure 1.6 (http://www.vegmeasure. us/index.htm) is a software package designed for objectively analyzing cover in vertical, near-earth imagery (Johnson et al.

each involving 1000 random points (image pixels) classified by the lead author. A new set of random points was generated for each bout. Three sampling bouts were applied to each image. B, Test image 2 with $20.2 \%$ shaded. C, Test image 3 where $49.4 \%$ of the quadrate was shaded. 
2003). Each analyst used the Calibrate Image Threshold function in VegMeasure to generate 100 random sample points on each test image and then visually classified the image pixel at each sample point. The grayscale threshold and shaded and unshaded percentages for each test image were determined, based on this point classification, using an algorithm in the software.

Point Sampling With Regular Grid. Simply point-sampling a digital image, without a threshold-based classification, may provide an objective means of classifying image features (Booth et al. 2005a, 2005b, 2005c, 2005d; Clark and Hardegree 2005). Using the image analysis software program, Samplepoint 1.43 (http://www.ars.usda.gov/services/software/ download.htm? softwareid=128; Booth et al. 2006), the analysts classified image pixels at each sample point within a regular grid of 100, 144, or 225 points. Time and shading percentage results from these three techniques were recorded separately.

Point Sampling With Random Points. To avoid sampling bias associated with regular grids, we used the VegMeasure software to generate and classify sets of 100, 144, and 225 random points for each image. Results from these three techniques were also recorded separately.

Standard Values Analysis. Accuracy of the shade measurement results from each of the eight image analysis techniques described above were determined by comparison to standard values established using a comprehensive point-sampling technique involving 1000 random points per image. Similar to the random point-sampling techniques above, each of the 1000 points were visually classified by the lead author, and the percentage of shaded points was calculated for each test image. Sampling bouts were repeated three times per image using a new set of random points for each bout. The mean shading percentage for each image was calculated from the results of these three sampling bouts and reported as the standard value. Differences between results from the eight different techniques, five analysts, and the standard values were reported as shadeassessment errors. These errors were recorded as the absolute values for statistical analysis.

\section{Statistical Analysis}

A completely randomized design with three factors, technique $(n=8)$, analyst $(n=5)$, and image $(n=3)$, was used in General Linear Model procedure (SAS 2003) to identify the most accurate and efficient of the eight image analysis techniques. The interaction of all three factors was employed as the error term $(\mathrm{df}=56)$. Mean separations for single factors were accomplished using a Fisher's Protected LSD test. Separation of least-squares means for the significant interactions was accomplished using an LSD adjustment for all pairwise comparisons. All differences reported were significant at $P<0.05$, unless stated otherwise.

\section{RESULTS}

\section{New Field Technique}

The field technique presented here provided a simple and rapid means of collecting digital images of stream-surface shading on
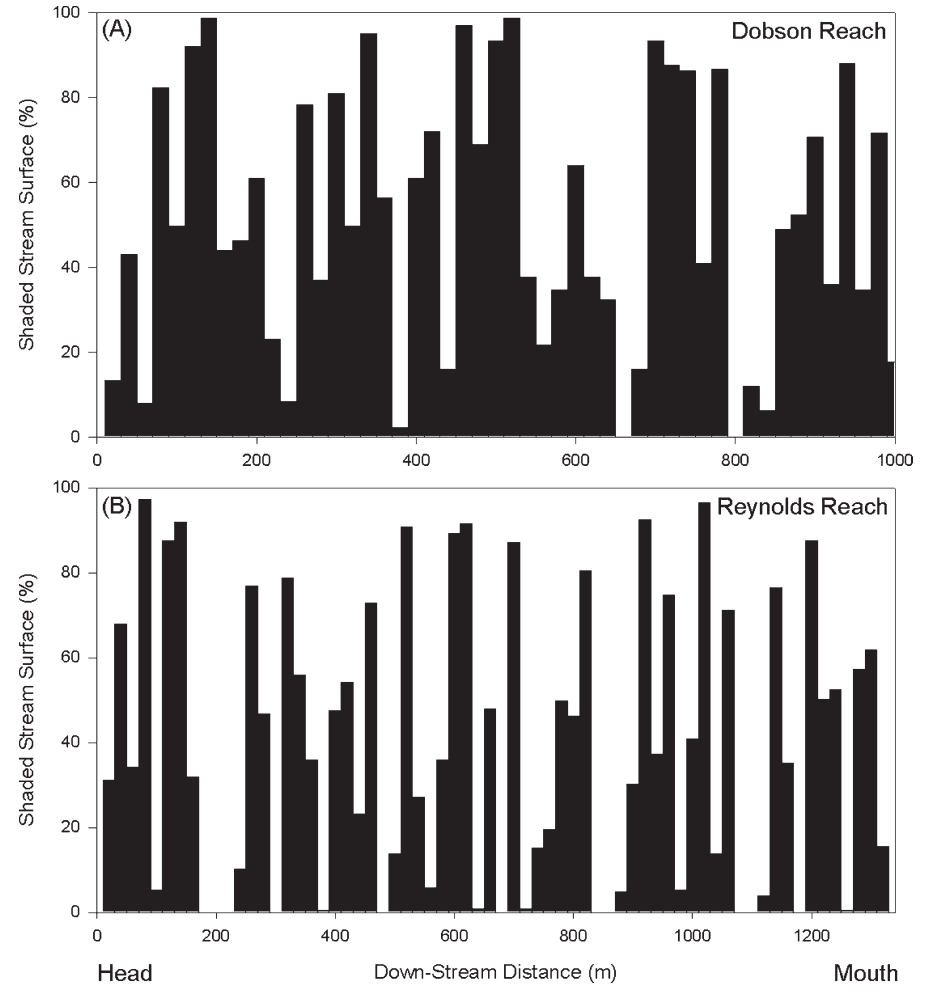

Figure 3. Shading profiles (\%) at solar noon ( $\pm 2 \mathrm{~h}$ ) for the $\mathbf{A}$, Dobson and $\mathbf{B}$, Reynolds stream reaches in the Reynolds Creek Experimental Watershed of southwestern Idaho based on digital image samples, each representing a $1-\mathrm{m}^{2}$ area of the stream surface and collected along the thalweg of each reach at $20-m$ intervals.

the Dobson $(n=50)$ and Reynolds $(n=66)$ study reaches. Figures $3 \mathrm{~A}$ and $3 \mathrm{~B}$ illustrate the midday (solar noon $\pm 2 \mathrm{~h}$ ) shading profile determined for each stream reach during 25 August and 22 August 2000, respectively. Shading on the Dobson reach ranged from $0 \%$ to $98.7 \%$ with mean and standard deviation (SD) of $51.1 \pm 30.9 \% \mathrm{SD}$. Shading mean for the Reynolds reach was $38.8 \pm 33.4 \%$ SD and ranged from $0 \%$ to $97.3 \%$.

Sampling of the Dobson reach required $124 \mathrm{~min}$, whereas the Reynolds reach took $163 \mathrm{~min}$ to sample. Average sampling field time required for each sample location was $33.4 \mathrm{~s} \pm 6.7$ SD for the Dobson reach with a range of 21-43 s. Locations on Reynolds required an average of $36.3 \mathrm{~s} \pm 7.6 \mathrm{SD}$ to sample with a range of 24-48 s.

\section{Image Analysis Technique Evaluation}

Image point sampling using 225 random points $(\bar{x}=1.9$ percentage points $\pm 1.9 \mathrm{SD})$ or 144 random points $(\bar{x}=3.2$ percentage points $\pm 2.4 \mathrm{SD}$ ) yielded the lowest error rate of the eight analysis techniques. Point sampling with 100 regularly spaced points resulted in the highest error rate $(\bar{x}=6.8$ percentage points $\pm 3.2 \mathrm{SD}$ ). Error rates among the five analysts were similar with an overall mean across techniques and test images of $\bar{x}=4.4$ percentage points \pm 3.2 SD. Error rates for shading analyses of Test image $1(29.0 \%$ shaded; Fig. $2 \mathrm{~A})$ were lowest $(\bar{x}=2.8$ percentage points $\pm 2.7 \mathrm{SD})$, and errors for Test image $2(20.2 \%$ shaded $)$ were highest $(\bar{x}=6.1$ percentage points \pm 3.4 SD; Fig. 2B). An interaction between 
analysis technique and test images $(P<0.001)$ was noted. Shading patterns in Test image 2 tended to be oriented parallel to columns of points within the grid used for the regular grid sampling techniques. This sampling bias likely caused the shading level of this image to be overestimated when using regular grids.

Time required to point sample the images with 100 and 144 random points was similar $(\bar{x}=44 \mathrm{~s} \pm 16 \mathrm{SD}$ and $\bar{x}=54 \mathrm{~s} \pm 26 \mathrm{SD}$, respectively) and less than the other six image analysis techniques. The subjective threshold required the longest time to complete $(\bar{x}=366 \mathrm{~s} \pm 232$ SD). Differences in analysis time were detected among the five analysts. Shading of Test image 2 required the least amount of time to analyze $(\bar{x}=133 \mathrm{~s} \pm 106 \mathrm{SD})$, whereas Test image 3 required the greatest time $(\bar{x}=166 \mathrm{~s} \pm 101 \mathrm{SD})$. Significant interactions were detected between both technique $X$ analyst and technique $\times$ image.

\section{DISCUSSION}

An approach combining the shade board field technique and the image point-sampling (e.g., 144-255 random points) analysis technique provides a simple, accurate, and relatively inexpensive means of directly assessing stream-surface shading. The approach could be used as the primary means of assessing shade for extensive stream networks or as a standard to quantify error where indirect sampling methods are employed.

The sampling approach we propose would be fundamentally different from canopy densiometer (Kelley and Krueger 2005), hemispherical photography (Ringold and Van Sickle 2003; Drever 2005; Lhotka and Loewenstein 2006), Solar Pathfinder (Platts et al. 1987; Platts and Nelson 1989; Tait et al. 1994; Maloney et al. 1999), and other commonly used techniques, in that we measured stream-surface shading directly rather than inferring potential shade from canopy cover or canopy images coupled with a superimposed path of the solar disk. Although our approach measures shading at a location for only an instant in time, this limitation can be overcome with repetitive sampling at the location thus yielding a shading estimate for the period of interest. Obviously, shorter intervals between samples will increase the accuracy of this shading estimate. This sampling approach is not designed, however, to model or estimate shade at times of the day or year not sampled because hemispherical cover from shade-casting objects is not imaged or quantified. The canopy-based techniques mentioned above, if precisely applied, may be used to model shading throughout the day, season, or year. The error associated these model predictions, however, is quite difficult to quantify without collecting some sort of direct measurements, such as shade board images, as a standard.

Based on our experience at Dobson Creek and Reynolds Creek, a team of two people can sample a $1-\mathrm{km}$ stream reach at 50 locations for three times (e.g., 0900, 1200, 1500 hours) during a normal work day $(8 \mathrm{~h})$, which includes flagging or staking each sample location for return visits. Processing and analysis of the resultant 150 shade board images, using 225 random point samples per image, took one analyst about $4 \mathrm{~h}$ to complete (data not shown). Consequently, directly imaging and analyzing stream-surface shading would likely be a viable approach for assessing shading dynamics within extensive stream networks.

This direct sampling approach is intuitively simple, such that technicians can readily learn both the field and image analysis techniques. Our evaluations suggest the approach is robust with similar results obtained from a variety of technicians. Materials required for construction of the white board, mast, and camera mount are readily available and inexpensive, which should encourage its use by natural resource managers and agencies with limited equipment budgets. Once images are obtained and processed, they can be tagged with a GPS location of the sample, stored in electronic format, and used as permanent record for future comparisons, such as determining trends in stream shading.

\section{MANAGEMENT IMPLICATIONS}

National forest plans, grazing allotment management plans, and other planning or regulatory documents currently specify stream-shading requirements, guidelines, or targets as means to mitigate excessive stream temperature and provide stream-bank stability and other ecological benefits. Our proposed shadesampling approach, combining field and image analysis techniques for direct measurement of stream shading, seems aptly suited for environmental monitoring under these management and regulatory systems. Given its simplicity, robustness, and low cost, this approach should provide an effective and efficient means of assessing shade for extensive stream systems. As a direct measurement of stream-surface shading, our approach could also provide standard data for evaluating error in cases where indirect, canopy-based techniques are employed as the primary shade-assessment tool.

\section{LITERATURE CITED}

BeschtA, R. L. 1997. Riparian shade and stream temperature: an alternative perspective. Rangelands 19:25-28.

BonHAm, C. D. 1987. Measurements for Terrestrial Vegetation. New York, NY, USA John Wiley and Sons. 338 p.

Booth, D. T., S. E. Cox, and R. D. Berryman. 2005a. Precision measurements from very large scale aerial digital imagery. Environmental Monitoring and Assessment 112:293-307.

Booth, D. T., S. E. Cox, and R. D. Berryman. 2006. Point sampling digital imagery with 'Samplepoint.' Environmental Monitoring and Assessment 123:97-108.

Booth, D. T., S. E. Cox, C. Fifield, M. Phillips, and N. Williamson. 2005b. Image analysis compared with other methods for measuring ground cover. Arid Land Research and Management 19:91-100.

Booth, D. T., S. E. Cox, AND D. E. JoHnson. 2005c. Detection-threshold calibration and other factors influencing digital measurements of bare ground. Rangeland Ecology and Management 58:598-604.

Booth, D. T., S. E. Cox, T. W. Meikle, and C. Fitzgerald. 2005d. The accuracy of ground cover measurements. Rangeland Ecology and Management 59:179-188.

Brown, G. W. 1970. Predicting the effect of clearcutting on stream temperatures. Journal of Soil and Water Conservation 25:11-13.

BunnelL, F. L., And D. J. Vales. 1990. Comparison of methods for estimating forest overstory cover: differences among techniques. Canadian Journal of Forest Research 20:101-107.

Chen, Y. D., R. F. Carsel, S. C. McCutcheon, and W. L. Nutter. 1998. Stream temperature simulation of forested riparian areas, I: watershed-scale model development. Journal of Environmental Engineering 124:304-314. 
Clark, P. D., and S. P. Hardegree. 2005. Quantifying vegetation change by point sampling landscape photography time series. Rangeland Ecology and Management 58:588-597.

Cooter, E. J., AND W. S. Cooter. 1990. Impacts of greenhouse warming on water temperature and water quality in the southern United States. Climate Research 1:1-12.

Cox, M. M., AND J. P. BoLte. 2007. A spatially explicit network-based model for estimating stream temperature distribution. Environmental Modelling and Software 22:502-514.

Cox, T. J., and T. C. Rutherford. 2000. Thermal tolerances of two stream invertebrates exposed to diurnally varying temperature. New Zealand Journal Marine and Freshwater Research 34:203-208.

Davies-Colley, R. J., and G. W. Payne. 1998. Measuring stream shade. Journal of the North American Benthological Society 17:250-260.

Davies-Colley, R. J., AND J. C. Rutherford. 2005. Some approaches for measuring and modeling riparian shade. Ecological Engineering 24:525-530.

Dickerson, B. R., AND G. L. VinYard. 1999. Effects of high chronic temperatures and diel temperature cycles on the survival and growth of Lahontan cutthroat trout. Transactions of the American Fisheries Society 128:516-521.

Drever, C. R. 2005. Assessing light and conifer growth in a riparian restoration treatment along Spirit Creek, British Columbia. Northwest Science 79:44-52.

GreIg-Smith, P. 1983. Quantitative plant ecology. 3rd ed. Berkeley, CA, USA: University of California Press. 357 p.

Hanson, C. L., D. Marks, and S. S. Van Vactor. 2001. Long-term climate database, Reynolds Creek Experimental Watershed, Idaho, United States. Water Resources Research 37:2839-2841.

Hawkins, C. P., J. N. Hogue, L. M. Decker, and J. W. Feminella. 1997. Channel morphology, water temperature, and assemblage structure of stream insects. Journal of the North American Benthological Society 16:728-749.

ICE, G. G., J. LIGHT, AND M. Reiter. 2004. Use of natural temperature patterns to identify achievable stream temperature criteria for forest streams. Western Journal of Applied Forestry 19:252-259.

Johnson, D. E., M. Vulfson, And M. Louhaichi. 2003. VegMeasure version 1.6 user's manual: VegMeasure project. Corvallis, OR, USA: Department of Rangeland Ecology and Management, Oregon State University. $50 \mathrm{p}$.

Kelley, C. E., and W. C. Krueger. 2005. Canopy cover and shade determinations in riparian zones. Journal of the American Water Resources Association 41:37-46.

LaRson, L. L., AND S. L. LaRSon. 1996. Riparian shade and stream temperature: a perspective. Rangelands 18:149-152.

Lhotka, J. M., AND E. F. Loewenstein. 2006. Indirect measurements for characterizing light along a gradient of mixed-hardwood riparian forest canopy structures. Forest Ecology and Management 226:310-318.

Malcolm, I. A., D. M. Hannah, M. J. Donaghy, C. Soulsby, and A. F. Youngson. 2004. The influence of riparian woodland on the spatial and temporal variability of stream water temperatures in an upland salmon stream. Hydrology and Earth Systems Sciences 8:449-459.
Maloney, S. B., A. R. Tiedemann, D. A. Higgins, T. M. Quigley, and D. B. Marx. 1999. Influence of stream characteristics and grazing intensity on stream temperatures in Eastern Oregon. Portland, OR, USA: USDA Forest Service, Pacific Northwest Research Station General Technical Report PNW-GTR-459. $19 \mathrm{p}$.

Moore, R. D., D. L. Spittlehouse, and A. Story. 2005. Riparian microclimate and stream temperature response to forest harvesting: a review. Journal of the American Water Resources Association 41:813-834.

Morrill, J. C., R. C. Bales, And M. H. ConkLin. 2005. Estimating stream temperature from air temperature: Implications for future water quality. Journal of Environmental Engineering 131:139-146.

NuttLE, T. 1997. Densiometer bias? are we measuring the forest or the trees? Wildlife Society Bulletin 25(3):610-611.

Paint Shop Pro Photo X2 [computer program]. 2000. Version 7.00. Fremont, CA, USA: Corel Corporation.

Platts, W. S., C. Armour, G. D. Booth, M. Bryant, J. L. Bufford, P. Cuplin, S. Jensen, G. W. Lienkaemper, G. W. Minshall, S. B. Monsen, R. L. Nelson, J. R. Sedell, and J. S. TuHy. 1987. Method for evaluating riparian habitats with applications to management. Ogden, UT, USA: USDA Forest Service Intermountain Research Station, General Technical Report INT-221.

PlatTs, W. S., and R. L. Nelson. 1989. Characteristics of riparian plant communities and streambanks with respect to grazing in northeastern Utah. In: R. E. Gresswell, B. A. Barton, and J. L. Kershner [eds.]. Practical approaches to riparian resource management and education workshop. Billings, MT, USA: USDI Bureau of Land Management. p. 73-81.

Ringold, P. L., AND J. VAN SickLe. 2003. Use of hemispheric imagery for estimating stream solar exposure. Journal of the American Water Resources Association 39:1373-1384.

Rutherford, J. C., S. Blackett, C. Blackett, L. Saito, and R. J. Davies-Colley. 1997. Predicting the effects of shade on water temperature in small streams. New Zealand Journal of Marine and Freshwater Research 31:707-722.

Rutherford, J. C., N. A. Marsh, P. M. Davies, and S. E. Bunn. 2004. Effects of patchy shade on stream water temperature: how quickly do small streams heat and cool? Marine and Freshwater Research 55:737-748.

Rutherford, J. C., M. R. Scarsbrook, and N. Broekhuizen. 2000. Grazer control of stream algae: modeling temperature and flood effects. Journal of Environmental Engineering 126:331-339.

SAS. 2003. SAS/STAT user's guide. Version 9.1. Cary, NC, USA: SAS Institute, Inc. $5136 \mathrm{p}$.

Tait, C. K., J. L. LI, G. A. Lambertı, T. N. Pearsons, and H. W. LI. 1994. Relationships between riparian cover and the community structure of high desert streams. Journal of the North American Benthological Society 13:45-56.

Teti, P. A., And R. G. PIKE. 2005. Selecting and testing an instrument for surveying stream shade. BC Journal of Ecosystems and Management 6:1-16.

US Environmental Protection Agency. 2003. EPA Region 10 guidance for Pacific Northwest State and Tribal Water Quality Standards. Seattle, WA, USA: EPA Region 10 Office of Water Report 910-B-03-002. 57 p. 